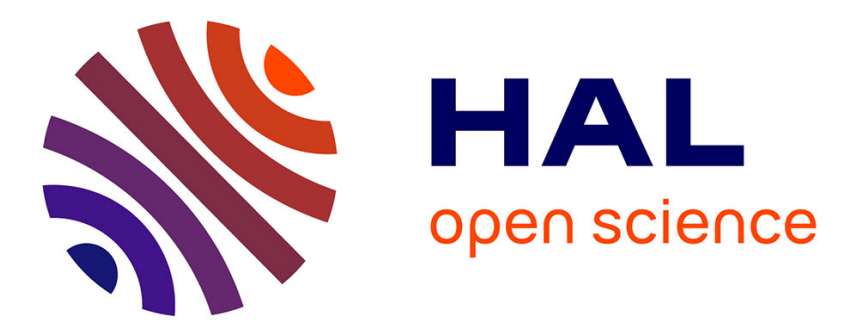

\title{
Length-weight relationships of 20 fish species from the Sine Saloum estuary, Senegal, West Africa
}

O. Sadio, François Le Loc'h, Monique Simier, Luis Tito de Morais

\section{To cite this version:}

O. Sadio, François Le Loc'h, Monique Simier, Luis Tito de Morais. Length-weight relationships of 20 fish species from the Sine Saloum estuary, Senegal, West Africa. Cybium: Revue Internationale d'Ichtyologie, 2021, 45 (2), pp.155-158. 10.26028/cybium/2021-452-007 . hal-03274388

\section{HAL Id: hal-03274388 \\ https://hal.science/hal-03274388}

Submitted on 30 Jun 2021

HAL is a multi-disciplinary open access archive for the deposit and dissemination of scientific research documents, whether they are published or not. The documents may come from teaching and research institutions in France or abroad, or from public or private research centers.
L'archive ouverte pluridisciplinaire HAL, est destinée au dépôt et à la diffusion de documents scientifiques de niveau recherche, publiés ou non, émanant des établissements d'enseignement et de recherche français ou étrangers, des laboratoires publics ou privés. 
Ichthyological Note

Length-weight relationships of 20 fish species from the Sine Saloum estuary, Senegal, West Africa

Oumar SADIO (1), François LE LOC'H (2), Monique SIMIER (3) \& Luis TITO DE MORAIS (3)

(1) IRD, Univ Brest, CNRS, Ifremer, LEMAR, BP 1386 Dakar, Senegal

(2) IRD, Univ Brest, CNRS, Ifremer, LEMAR, F-29280 Plouzane, France

(3) MARBEC, Univ Montpellier, CNRS, Ifremer, IRD, 34203 Sète, France

Oumar Sadio: oumar.sadio@ird.fr ; 0000-0002-6621-2490

François Le Loc'h: francois.le.loch@ird.fr; 0000-0002-3372-6997

Monique Simier: monique.simier@ird.fr ; 0000-0002-8436-5925

Luis Tito de Morais: luis.tito-de-morais@ird.fr; 0000-0001-8580-1808

Characters: 7401 (from introduction to the end of discussion); Tabs: $\mathbf{2}$

Possible reviewers recommended by the authors:

- Philippe Laléyé : laleyephilippe@gmail.com

- Thomas Changeux : Thomas.changeux@ird.fr

- Flavia Lucena Fredou : flavialucena@hotmail.com

- Rachid Amara : rachid.amara@univ-littoral.fr

Running title: Length-weight relationships of fish from Sine Saloum estuary in Senegal 


\section{ABSTRACT}

Length-weight relationships $\left(\mathrm{W}=\mathrm{aL}^{\mathrm{b}}\right)$ were estimated for 20 fish species collected during scientific fishing surveys conducted from April 1990 to October 2012 in the Sine Saloum estuary, Senegal, using purse seine, beach seine and fyke-net. The number of individuals varied from 10 (Hemicaranx bicolor) to 777 (Carlarius latiscutatus). Fish length ranged from $4.5 \mathrm{~cm}$ total length (Sphoeroides marmoratus) to $130.0 \mathrm{~cm}$ total length (Sphyraena afra). The values of parameter $b$ in the LWR equations varied from 2.687 (Hemicaranx bicolor) to 3.334 (Citharichthys stampflii). The coefficient of determination $\left(\mathrm{r}^{2}\right)$ varied between 0.953 (Sphoeroides marmoratus) and 0.996 (Sphyraena afra). The length-weight relationship has never been studied before in Sine Saloum estuary for 13 fish species (Carlarius parkii, Batrachoides liberiensis, Caranx senegallus, Hemicaranx bicolor, Trachinotus teraia, Elops senegalensis, Lutjanus goreensis, Citharichthys stampflii, Psettodes belcheri, Dagetichthys lusitanicus, Sphyraena afra, Sphyraena guachancho and Sphoeroides marmoratus). This study provided LWRs that are not available in FishBase (Froese and Pauly, 2020) for Carlarius latiscutatus, Carlarius parkii, Batrachoides liberiensis, Caranx senegallus, Hemicaranx bicolor, Cynoglossus senegalensis, Fontitrygon margarita, Plectorhinchus macrolepis, Pomadasys perotaei, Lutjanus goreensis, Citharichthys stampflii, Psettodes belcheri, Dagetichthys lusitanicus and Sphoeroides marmoratus. It also provided size ranges that are not specified for LWRs in FishBase for Ephippion guttifer, Elops senegalensis, Pseudotolithus senegalensis, Pseudotolithus senegallus and Sphyraena afra. In addition, new maximum lengths are presented for Plectorhinchus macrolepis and Citharichthys stampflii. The parameters obtained from this study will be useful for proper fish population management in West African fisheries.

\section{French title:}

Relations taille-poids chez 20 espèces de poissons de l'estuaire du Sine Saloum au Sénégal, en Afrique de l'Ouest

\section{RESUME.}

Les relations taille-poids $\left(\mathrm{W}=\mathrm{aL}^{\mathrm{b}}\right)$ ont été estimées pour 20 espèces de poisson collectées au cours des missions de pêche scientifique effectuées d'avril 1990 à octobre 2012 dans l'estuaire du Sine Saloum, Sénégal, avec comme engin de pêche la senne tournante 
coulissante, la senne de plage et la nasse. Le nombre d'individus par espèce variait entre 10 (Hemicaranx bicolor) et 777 (Carlarius latiscutatus). La taille des poissons variait entre 4,5 $\mathrm{cm}$ de longueur totale (Sphoeroides marmoratus) et 130,0 cm de longueur totale (Sphyraena afra). Les valeurs du paramètre $b$ de la relation taille-poids variaient de 2,687 (Hemicaranx bicolor) à 3,334 (Citharichthys stampflii). Le coefficient de détermination $\left(\mathrm{r}^{2}\right)$ variait entre 0,953 (Sphoeroides marmoratus) et 0,996 (Sphyraena afra). La relation taille-poids n'a jamais été étudiée auparavant pour 13 espèces de poissons (Carlarius parkii, Batrachoides liberiensis, Caranx senegallus, Hemicaranx bicolor, Trachinotus teraia, Elops senegalensis, Lutjanus goreensis, Citharichthys stampflii, Psettodes belcheri, Dagetichthys lusitanicus, Sphyraena afra, Sphyraena guachancho and Sphoeroides marmoratus) dans l'estuaire du Sine Saloum. Cette étude a fourni des informations sur les relations taille-poids qui n'existent pas encore dans FishBase (Froese and Pauly, 2020) pour les espèces Carlarius latiscutatus, Carlarius parkii, Batrachoides liberiensis, Caranx senegallus, Hemicaranx bicolor, Cynoglossus senegalensis, Fontitrygon margarita, Plectorhinchus macrolepis, Pomadasys perotaei, Lutjanus goreensis, Citharichthys stampflii, Psettodes belcheri, Dagetichthys lusitanicus and Sphoeroides marmoratus. Elle a aussi fourni des gammes de taille qui ne sont pas spécifiées dans FishBase pour la relation taille-poids de 5 espèces (Ephippion guttifer Elops senegalensis, Pseudotolithus senegalensis, Pseudotolithus senegallus and Sphyraena afra). En outre, de nouvelles tailles maximales sont présentées pour Plectorhinchus macrolepis et Citharichthys stampflii. Les paramètres obtenus à partir de cette étude seront utiles pour une bonne gestion des populations de poissons dans les pêcheries d'Afrique de l'Ouest.

Keywords: Length-weight relationship, Fish species, Saloum estuary, Senegal.

\section{Introduction}

The relationship between length and weight of individuals in a fish population, with several other essential parameters is a basic tool for fishery scientists, managers and biologists to assess the natural population dynamics (Le Cren, 1951; Froese, 2006). Fish length-weight relationships are useful in the estimation of fish population size (Dulčić and Kraljević, 1996; Froese, 2006; Giarrizzo et al., 2015), of biomass from length observations (Petrakis and Stergiou, 1995; Gonçalves et al., 1997) and to assess stocks (Hampton, 2000; Fromentin and 
Fonteneau, 2001). Studies on length-weight relationships provide information about growth patterns (Okgerman, 2005), fisheries biology and population dynamics (Sivashanthini, 2008).

In this study, we assessed length-weight relationships for 20 species from the Sine Saloum estuary. This work complements those of Ecoutin and Albaret (2003) and Ndiaye et al. (2015) on some species in the Sine Saloum estuary. In addition, we have drawn up a table of LWRs of certain species whose LWRs have already been studied in the Sine Saloum estuary in order to observe differences, bearing in mind that the sampling methodologies are not the same compared to that of Ndiaye et al. (2015).

\section{Materials and Methods}

The Sine Saloum estuary is located $100 \mathrm{~km}$ south of Dakar, in Senegal, between $13^{\circ} 55^{\prime}$ and $14^{\circ} 10^{\prime}$ North and $16^{\circ} 03^{\prime}$ and $16^{\circ} 50^{\prime}$ 'West. The Sine Saloum is an inverse estuary characterized by an increase in salinity from downstream to upstream in all seasons. The system comprises three main branches: from north to south, the Saloum, the Diomboss and the Bandiala, connected to each other by a vast network of small mangrove creeks locally named "bolong". Mangrove forests cover almost the entire southern portion of the system and progressively diminish in the North (Diouf, 1996; Simier et al., 2004). Data were collected during scientific fishing surveys. The whole Sine Saloum estuary was sampled first from April 1990 to May 1993 (Diouf, 1996), with occasional samplings in 1994 and 1997, and then from 2002 to 2003 (Ecoutin et al., 2010), with additional samplings from 2004 to 2007. The Bamboung bolong, a small tributary of the Diomboss, which has become a Marine Protected Area in 2004, was subject to a biological monitoring from 2003 to 2012 and the Sangako bolong, not far from the Bamboung Marine Protected Area but open to fishing, was also sampled for comparison from 2008 to 2012 (Ecoutin et al., 2014; Sadio et al., 2015). Most sampling was carried out during the three main hydro-climatic seasons of the region, i.e. in March (end of the cool dry season), May-June (end of the hot dry season) and October (end of the wet season). The fish were caught using a purse seine (length $250 \mathrm{~m}$, height $20 \mathrm{~m}$, $14 \mathrm{~mm}$ mesh size; see Simier et al., 2004), a beach seine (180 m length, $9 \mathrm{~m}$ height and 25 $\mathrm{mm}$ mesh net; see Diouf, 1996) and fyke-nets (diameter, $40 \mathrm{~cm}$; length, $3 \mathrm{~m}$; with two 1.5-m wings adjacent to the opening; see Gning et al., 2008). Fish were identified to the species level and measured to the nearest $\mathrm{mm}$ (fork length for fish with a forked caudal fin with crescent or indented form; total length for species with a rounded caudal fin with a pointed or truncated form; disc width for rays) and weighed to the nearest $\mathrm{g}$. All data are available in 
PPEAO database (Simier et al., 2019). Linear regressions of $\log (\mathrm{W}) v s . \log (\mathrm{L})$, where $\mathrm{W}$ is total weight in $\mathrm{g}$, $\mathrm{L}$ is total or fork length or disc width in $\mathrm{cm}$ were calculated to obtain the length-weight relationship of the form $\mathrm{W}=\mathrm{aL}^{\mathrm{b}}$ (Froese, 2006) where $\log (\mathrm{a})$ is the intercept and $b$ is the slope of the regression. Length and weight data were first plotted to identify outliers, the most extreme of which were finally excluded from the analyses. Samples with $n$ $<10$ were excluded from the regression analyses.

\section{Results}

Twenty fish species belonging to 14 families were considered in this study, making up 3293 individuals measured in the whole Sine Saloum estuary. Sample size, length and weight ranges, parameters of the LWR equations with $95 \%$ confidence limits and values of the determination coefficient $r^{2}$ were computed for the 20 species and reported in Table 1 . The sample size for a given species, varied from 10 (Hemicaranx bicolor) to 777 (Carlarius latiscutatus) individuals. Fish size ranged from $4.5 \mathrm{~cm}$ total length (Sphoeroides marmoratus) to $130 \mathrm{~cm}$ fork length (Sphyraena afra). The values of parameter b in the LWR equations varied from 2.687 (Hemicaranx bicolor) to 3.334 (Citharichthys stampflii). Linear regressions were significant for all species $(\mathrm{p}<0.001)$ and provided suitable adjustments: the coefficient of determination $\left(\mathrm{r}^{2}\right)$ varied between 0.953 (Sphoeroides marmoratus, $\mathrm{n}=58$ ) and 0.996 (Sphyraena afra, $\mathrm{n}=68$ ). For 7 of the 20 species, LWRs have already been published for the Sine Saloum estuary (Table 2) but with a smaller number of individuals (Fontitrygon margarita, Plectorhinchus macrolepis) or with a smaller size range (Pseudotolithus senegalensis) or with both a smaller number of individuals and a smaller size range (Carlarius latiscutatus, Cynoglossus senegalensis, Pomadasys perotaei, Ephippion guttifer). For the remaining 13 fish species, no information on LWRs was yet available in Senegal.

\section{Discussion}

The use of fishing gears with small mesh sizes $(14 \mathrm{~mm})$ allowed the sampling of a large range of sizes for most species from juveniles to adults. The Sine Saloum estuary is known to be a nursery area frequented by juvenile fish (Vidy, 2000) and a reproduction area (Diouf, 1996, Panfili et al., 2004a, b; Panfili et al., 2006; Albaret et al., 2005; Diop et al., 2017), what reflects the large size range of several species sampled. 
This study provided LWRs that are not available in FishBase (Froese and Pauly, 2020) for Carlarius latiscutatus, Carlarius parkii, Batrachoides liberiensis, Caranx senegallus, Hemicaranx bicolor, Cynoglossus senegalensis, Fontitrygon margarita, Plectorhinchus macrolepis, Pomadasys perotaei, Lutjanus goreensis, Citharichthys stampflii, Psettodes belcheri, Dagetichthys lusitanicus and Sphoeroides marmoratus. It also provided size ranges that are not specified for LWRs in FishBase for Ephippion guttifer Elops senegalensis, Pseudotolithus senegalensis, Pseudotolithus senegallus and Sphyraena afra. In addition, new maximum total lengths are presented for Plectorhinchus macrolepis $(53.8 \mathrm{~cm}$ vs. $45.0 \mathrm{~cm})$ and Citharichthys stampflii $(17.5 \mathrm{~cm}$ vs. $16.0 \mathrm{~cm})$. For the 7 species already studied in the Sine Saloum estuary, the differences can be due to the difference in size range or number of individuals in the case of the species studied by Ecoutin et Albaret (2003) and by differences in sampling method and equipment, season and area for the species studied by Ndiaye et al. (2015).

For all of the studied species in this study, the $b$ values were generally in agreement with previous results by Froese (2006) i.e. b value comprised between 2.5 and 3.5. Also, it is well known that the $b$ value represents the body form, and is directly related to the weight affected by ecological factors such as temperature, food supply, spawning conditions and other factors (Ricker, 1973). Regression results suggest that the data from this study and the results presented here are reliable and can enriched Senegalese length-weight relationships in FishBase (Froese and Pauly, 2020). They will be a useful tool to increase the ecological knowledge of these species in Sine Saloum estuary.

\section{Acknowledgements}

The results presented here are from the multidisciplinary program linked to the projects Narou Heuleuk (FFEM/AFD/ONG Oceanium/IRD), AMPHORE (ANR Biodiversity) and Cepia (AFD/CSRP/UICN/IRD). The author are grateful to the LEMAR team in Dakar and the fishermen and their team leader Mbaye Mbengue, also to the crew of the Diassanga research vessel and its captain François Sanseo, without whom these results could not have been obtained. 


\section{REFERENCES}

Albaret, J. J., Simier, M., \& Sadio, O. (2005). Suivi biologique des peuplements de poissons d'une aire protégée en zone de mangrove: le bolon de Bamboung (Sine-Saloum, Sénégal). Rapport final. Rapport de convention Narou Heuleuk/ AFD/ IRD, Dakar, juillet 2005. $80 \mathrm{pp}$. http://horizon.documentation.ird.fr/exl-doc/pleins_textes/divers1205/010055094.pdf.

Diop, K., Diouf, K., Diolne, M. D., Diadhiou, H. D., Thiaw, M., Ndiaye, P., \& Jouffre D. (2017). Study comparing the reproductive traits of the catfish, Arius latiscutatus (Günther, 1864) inside and outside the Bamboung marine protected area, Saloum Delta, Senegal. Int. j. fish. aquat. stud, 5, 91-99.

Diouf, P. S. (1996). Les peuplements de poissons des milieux estuariens de l'Afrique de l'Ouest : l'exemple de l'estuaire hyperhalin du Sine Saloum. Ph.D. Thesis, Université de Montpellier II, Montpellier. 177p. http://www.bondy.ird.fr/pleins textes/pleins textes_7/TDM_7/010008130.pdf.

Dulčić, J., \& Kraljević, M. (1996). Weight-length relationships for 40 fish species in the eastern Adriatic (Croatian waters). Fish. Res., 28, 243-251. doi: 10.1016/01657836(96)00513-9

Ecoutin, J. M., \& Albaret, J. J. (2003). Relation longueur-poids pour 52 espèces de poissons des estuaires et lagunes de l'Afrique de l'Ouest. Cybium, 27, 3-9.

Ecoutin, J. M., Simier, M., Albaret, J. J., Laë, R., Tito de Morais, L. (2010). Changes over a decade in fish assemblages exposed to both environmental and fishing constraints in the Sine Saloum estuary (Senegal). Estuar. Coast. Shelf Sci., 87, 284-292. doi: 10.1016/j.ecss.2010.01.009

Ecoutin, J. M., Simier, M., Albaret, J.-J., Laë, R., Raffray, J., Sadio, O., Tito de Morais, L. (2014). Ecological field experiment of short-term effects of fishing ban on fish assemblages in a tropical estuarine MPA. Ocean Coast Manag, 100, 74-85. doi: 10.1016/j.ocecoaman.2014.08.009.

Froese, R., \& Pauly D. (2020). FishBase. World Wide Web electronic publication. www. fishbase.org (accessed 09/2020).

Froese, R. (2006). Cube law, condition factor and weight-length relationships: history, metaanalysis and recommendations. J. Appl. Ichthyol., 22, 241-253. doi: 10.1111/j.14390426.2006.00805.x

Fromentin, J. M., \& Fonteneau, A. (2001). Fishing effects and life history traits: a case study comparing tropical versus temperate tunas. Fish. Res., 53, 133-150. doi: 
Giarrizzo, T., de Sena Oliveira, R. R., Costa Andrade, M., Pedrosa Gonçalves, A., Barbosa, T. A. P., Martins, A. R., Marques, D. K., Brito dos Santos, J. L., de Paula da Silva Frois, R., Oliveira de Albuquerque, T. P., Fogaca de Assis Montag, L., Camargo, M. \& Melo de Sousa, L. (2015). Length-weight and length-length relationships for 135 fish species from the Xingu River (Amazon Basin, Brazil). J. Appl. Ichthyol, 31, 415424. doi: 10.1111/jai.12677

Gning, N., Vidy, G., \& Thiaw, O. T. (2008). Feeding ecology and ontogenic diet shifts of juvenile fish species in an inverse estuary: The Sine-Saloum, Senegal. Estuarine, Coastal and Shelf Science, 76, 395-403. doi: 10.1016/j.ecss.2007.07.018

Gonçalves, J. M. S., Bentes, L., Lino, P. G., Ribeiro, J., Canário, A. V. M., \& Erzini, K. (1997). Weight-length relationships for selected fish species of the small-scale demersal fisheries of the south and southwest coast of Portugal. Fish. Res., 30, 253256. doi: 10.1016/s0165-7836(96)00569-3

Hampton, J. (2000). Natural mortality rates in tropical tunas: size really does matter. Can. J. Fish. Aquat. Sci., 57, 1002-1010. doi: 10.1139/199-287

Le Cren, E. D. (1951). The length-weight relationship and seasonal cycle in gonad weight and condition in the perch (Perca fluviatilis). J. Anim. Ecol., 20, 201-219. doi: $10.2307 / 1540$.

Ndiaye, W., Sarr, A., Diouf, M., Faye, A., \& Mbodji, A. (2015). Length-weight relationships of some fish species from the Bandiala River in Saloum Delta, Senegal. Int. J. Adv. Res., 3, 132-138.

Okgerman, H. (2005). Seasonal variations in the length-weight relationship and condition factor of rudd (Scardinius erythrophthalmus L.) in Sapanca Lake. Int. J. Zool. Res., 1, 6-10. doi: 10.3923/ijzr.2005.6.10

Panfili, J., Durand, J. D., Mbow, A., Guinand, B., Diop, K., Kantoussan, J., Thior, D., Albaret, J. J., \& Laë, R. (2004a). Influence of salinity on life history traits of the bonga shad Ethmalosa fimbriata (Pisces, Clupeidae): comparison between the Gambia and Saloum estuaries. Mar. Ecol. Prog. Ser., 270, 241-257. doi: $10.3354 /$ meps 270241

Panfili, J., Mbow, A., Durand, J. D., Diop, K., Diouf, K., Thior, D., \& Laë, R. (2004b). Influence of salinity on the life-history traits of the West African black-chinned tilapia (Sarotherodon melanotheron): comparison between the Gambia and Saloum estuaries. Aquat. Living Resour., 17, 65-74. doi: 10.1051/alr:2004002

Panfili, J., Thior, D., Ecoutin, J. M., Ndiaye, P., \& Albaret, J. J. (2006). Influence of salinity 
on the size at maturity for fish species reproducing in contrasting West African estuaries. J. Fish. Biol., 69, 95-113. doi: 10.1111/j.1095-8649.2006.01069.x

Petrakis, G., \& Stergiou, K. I. (1995). Weight-length relationships for 33 fish species in Greek waters. Fish. Res., 21, 465-469. doi: 10.1016/0165-7836(94)00294-7

Ricker, W.E. 1973. Linear regressions in fishery research. J. Fish. Res. Board. Can., 30: 409-

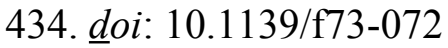

Sadio, O., Simier, M., Ecoutin, J.-M., Raffray, J., Laë, R., \& Tito de Morais, L. (2015). Effect of a marine protected area on tropical estuarine fish assemblages: Comparison between protected and unprotected sites in Senegal. Ocean. Coast. Manag., 116, 257-269. doi: 10.1016/j.ocecoaman.2015.08.004.

Simier, M., Blanc, L., Aliaume, C., Diouf, P. S., \& Albaret, J. J. (2004). Spatial and temporal structure of fish assemblages in an "inverse estuary", the Sine Saloum system (Senegal). Estuar. Coast. Shelf Sci., 59, 69-86. doi: 10.1016/j.ecss.2003.08.002

Simier, M., Ecoutin, J. M., \& Tito de Morais, L. (2019). The PPEAO experimental fishing dataset: Fish from West African estuaries, lagoons and reservoirs. Biodivers. Data J., 7:e31374, doi: 10.3897/BDJ.7.e31374.

Sivashanthini, K. (2008). Length-weight relationships and condition of gerreids (Pisces: Gerreidae) from the Parangipettai waters (SE coast of India). Asian Fish. Sci., 21, 405-419.

Vidy, G. (2000) Estuarine and mangrove systems and the nursery concept: which is which? The case of the Sine Saloum system (Senegal). Wetl. Ecol. Manag., 8, 37-51. doi: 10.1023/a: 1008402905530 
Table 1. Length-weight relationship (LWR) of 20 fish species from the Sine Saloum estuary in Senegal, from April 1990 to October 2012 . Species: a, fork length; b, Total length; c, Disc width. Abbreviations: n, sample size; Max, maximum; Min, minimum; a and b, parameters of LWR; CL, confidence limits; $r^{2}$, coefficient of determination.

\begin{tabular}{|c|c|c|c|c|c|c|c|}
\hline \multirow{2}{*}{ Family } & \multirow{2}{*}{ Species } & \multirow{2}{*}{$\mathbf{n}$} & \multirow{2}{*}{$\begin{array}{c}\begin{array}{c}\text { Length } \\
\text { (cm) }\end{array} \\
\text { Min-Max }\end{array}$} & \multirow{2}{*}{$\begin{array}{l}\text { Weight (g) } \\
\text { Min-Max }\end{array}$} & \multicolumn{3}{|c|}{ Relationship parameters } \\
\hline & & & & & a $(95 \%$ CL) & b $(95 \%$ CL) & $\mathbf{r}^{2}$ \\
\hline \multirow{2}{*}{ Ariidae } & Carlarius latiscutatus ${ }^{a}$ (Günther, 1864) & 777 & $15.5-61.4$ & $48-4100$ & $0.006(0.005-0.006)$ & $3.2367(3.2082-3.2652)$ & 0.985 \\
\hline & Carlarius parkii $^{a}$ (Günther, 1864) & 460 & $14.8-52.5$ & $39-2225$ & $0.009(0.008-0.010)$ & $3.1236(3.0941-3.1531)$ & 0.990 \\
\hline Batrachoididae & Batrachoides liberiensis ${ }^{b}$ (Steindachner, 1867) & 212 & $5.0-32.8$ & $2-630$ & $0.014(0.012-0.017)$ & $3.0541(2.9965-3.1117)$ & 0.981 \\
\hline \multirow{3}{*}{ Carangidae } & Caranx senegallus ${ }^{a}$ Cuvier, 1833 & 43 & $8.6-51.5$ & $9-2035$ & $0.013(0.011-0.017)$ & $3.0885(3.0048-3.1722)$ & 0.993 \\
\hline & Hemicaranx bicolor ${ }^{a}$ (Günther, 1860) & 10 & $6.2-12.6$ & $5-34$ & $0.036(0.021-0.060)$ & $2.6871(2.4417-2.9324)$ & 0.988 \\
\hline & Trachinotus teraia ${ }^{a}$ Cuvier, 1832 & 140 & $15.2-67.0$ & $80-8250$ & $0.015(0.012-0.018)$ & $3.1302(3.0754-3.185)$ & 0.989 \\
\hline Cynoglossidae & Cynoglossus senegalensis ${ }^{b}$ (Kaup, 1858) & 184 & $11.6-61.0$ & $6-677$ & $0.005(0.004-0.006)$ & $2.9209(2.8778-2.9640)$ & 0.990 \\
\hline Dasyatidae & Fontitrygon margaritac (Günther, 1870) & 71 & $10.0-58.5$ & $37-9200$ & $0.034(0.026-0.044)$ & $3.0731(2.9875-3.1588)$ & 0.987 \\
\hline Elopidae & Elops senegalensis ${ }^{a}$ Regan, 1909 & 75 & $17.4-55.3$ & $45-1545$ & $0.010(0.008-0.013)$ & $2.9444(2.8673-3.0214)$ & 0.988 \\
\hline \multirow{2}{*}{ Haemulidae } & Plectorhinchus macrolepis ${ }^{b}$ (Boulenger, 1899) & 110 & $14.9-53.8$ & $56-2834$ & $0.014(0.012-0.017)$ & $3.0920(3.0320-3.15210)$ & 0.990 \\
\hline & Pomadasys perotaei $^{a}$ (Cuvier, 1830) & 696 & $8.0-34.5$ & $8-554$ & $0.017(0.016-0.018)$ & $2.9762(2.9574-2.9949)$ & 0.993 \\
\hline Lutjanidae & Lutjanus goreensis $^{b}$ (Valenciennes, 1830$)$ & 112 & $23.8-59.0$ & $213-3460$ & $0.013(0.010-0.016)$ & $3.0402(2.9742-3.1062)$ & 0.987 \\
\hline Paralichthyidae & Citharichthys stampflii $^{b}$ (Steindachner, 1894) & 68 & $5.3-17.5$ & $1-58$ & $0.004(0.003-0.005)$ & $3.3341(3.1933-3.4749)$ & 0.971 \\
\hline Psettodidae & Psettodes belcheri ${ }^{b}$ Bennett, 1831 & 13 & $15.0-44.4$ & $36-880$ & $0.009(0.004-0.020)$ & $3.0639(2.8164-3.3114)$ & 0.985 \\
\hline Sciaenidae & Pseudotolithus senegalensis ${ }^{b}$ (Valenciennes, 1833) & 32 & $11.5-38.4$ & $11-441$ & $0.006(0.004-0.007)$ & $3.1000(3.0100-3.1900)$ & 0.994 \\
\hline Soleidae & Dagetichthys lusitanicus $^{b}$ (de Brito Capello, 1868) & 14 & $10.0-39.0$ & $5-468$ & $0.003(0.002-0.004)$ & $3.2626(3.119-3.4063)$ & 0.995 \\
\hline \multirow{2}{*}{ Sphyraenidae } & Sphyraena afra ${ }^{a}$ Peters, 1844 & 68 & $18.0-130.0$ & $31-11500$ & $0.006(0.005-0.007)$ & $2.9882(2.9442-3.0322)$ & 0.996 \\
\hline & Sphyraena guachancho ${ }^{a}$ Cuvier, 1829 & 26 & $16.1-33.0$ & $25-233$ & $0.009(0.006-0.014)$ & $2.8756(2.7537-2.9974)$ & 0.990 \\
\hline \multirow{2}{*}{ Tetraodontidae } & Ephippion guttifer ${ }^{b}$ (Bennett, 1831) & 124 & $8.4-60.2$ & $15-4150$ & $0.020(0.017-0.023)$ & $2.9911(2.9488-3.0334)$ & 0.994 \\
\hline & Sphoeroides marmoratus ${ }^{b}$ (Lowe, 1838) & 58 & $4.5-12.2$ & $2-31$ & $0.024(0.016-0.031)$ & $2.8146(2.6465-2.9828)$ & 0.953 \\
\hline
\end{tabular}


Table 2. Synthesis of studies on Length-weight relationship (LWR) of 7 fish species from the Sine Saloum estuary in Senegal studied before (Ecoutin and Albaret, 2003; Ndiaye et al., 2015). Abbreviations: n, sample size; Max, maximum; Min, minimum; a and b, parameters of LWR; TL, total length; FL, fork length; SL, standard length; DW, disc width; CL, confidence limits if available; $\mathrm{r}^{2}$, coefficient of determination.

\begin{tabular}{|c|c|c|c|c|c|c|c|c|}
\hline \multirow{2}{*}{ Species } & \multirow{2}{*}{$\mathbf{n}$} & \multirow{2}{*}{$\begin{array}{c}\text { Length } \\
\text { Min - Max }\end{array}$} & \multirow{2}{*}{$\begin{array}{l}\text { Weight (g) } \\
\text { Min - Max }\end{array}$} & \multicolumn{3}{|c|}{ Relationship parameters } & \multirow{2}{*}{ Author } & \multirow{2}{*}{ Ecosystem } \\
\hline & & & & a $(95 \% \mathrm{CL})$ & b $(95 \%$ CL) & $\mathbf{r}^{2}$ & & \\
\hline \multicolumn{9}{|c|}{ Ariidae } \\
\hline \multirow[t]{2}{*}{ Carlarius latiscutatus (Günther, 1864) } & 58 & $160-523(\mathrm{FL})(\mathrm{mm})$ & & $1.11 .10^{-5}$ & 3.028 & 0.964 & Ecoutin and Albaret, 2003 & Saloum (Senegal) \\
\hline & 130 & $20.5-28.4(\mathrm{TL})(\mathrm{cm})$ & $52.4-72.6$ & 0.025 & 2.540 & 0.920 & Ndiaye et al., 2015 & Saloum (Senegal) \\
\hline \multicolumn{9}{|c|}{ Cynoglossidae } \\
\hline Cynoglossus senegalensis (Kaup, 1858) & 34 & $111-540(\mathrm{TL})(\mathrm{mm})$ & & $3.91 \cdot 10^{-5}$ & 2.625 & 0.882 & Ecoutin and Albaret, 2003 & Saloum (Senegal) \\
\hline \multicolumn{9}{|c|}{ Dasyatidae } \\
\hline Fontitrygon margarita (Günther, 1870) & 27 & $100-585(\mathrm{DW})(\mathrm{mm})$ & & $16.83 .10-5$ & 2.748 & 0.924 & Ecoutin and Albaret, 2003 & Saloum (Senegal) \\
\hline \multicolumn{9}{|c|}{ Haemulidae } \\
\hline \multirow[b]{2}{*}{ Plectorhinchus macrolepis (Boulenger, 1899) } & 23 & $149-670(\mathrm{TL})(\mathrm{mm})$ & & 4.29. $10-5$ & 2.855 & 0.978 & Ecoutin and Albaret, 2003 & Saloum (Senegal) \\
\hline & 16 & $16.0-31.5(\mathrm{TL})(\mathrm{cm})$ & $42.5-295.4$ & 0.030 & 2.830 & 0.960 & Ndiaye et al., 2015 & Saloum (Senegal) \\
\hline \multirow{2}{*}{ Pomadasys perotaei (Cuvier, 1830) } & 178 & $100-281(\mathrm{FL})(\mathrm{mm})$ & & 0.001 & 2.677 & 0.966 & Ecoutin and Albaret, 2003 & Saloum (Senegal) \\
\hline & 57 & $15.1-32.2(\mathrm{TL})(\mathrm{cm})$ & $37.8-286.2$ & 0.032 & 2.750 & 0.970 & Ndiaye et al., 2015 & Saloum (Senegal) \\
\hline \multicolumn{9}{|c|}{ Sciaenidae } \\
\hline Pseudotolithus senegalensis (Valenciennes, 1833) & 78 & $18.5-28.0(\mathrm{TL})(\mathrm{cm})$ & $52.1-166.2$ & 0.015 & 2.79 & 0.980 & Ndiaye et al., 2015 & Saloum (Senegal) \\
\hline \multicolumn{9}{|c|}{ Tetraodontidae } \\
\hline Ephippion guttifer (Bennett, 1831) & 58 & $13.5-30.5(\mathrm{TL})(\mathrm{cm})$ & $51.5-578.3$ & 0.025 & 2.92 & 0.990 & Ndiaye et al., 2015 & Saloum (Senegal) \\
\hline
\end{tabular}

